Check for updates

Cite this: RSC Adv., 2021, 11, 17080

Received 17th November 2020

Accepted 1st May 2021

DOI: 10.1039/dOra09744f

rsc.li/rsc-advances

\section{Adsorption process and mechanism of heavy metal ions by different components of cells, using yeast (Pichia pastoris) and $\mathrm{Cu}^{2+}$ as biosorption models}

\author{
Xinggang Chen, (D) ab Zhuang Tian, (D) ab Haina Cheng, ${ }^{\text {*ab }}$ Gang Xu*c \\ and Hongbo Zhou ${ }^{\star a b}$
}

Microbial biomass has been recognized as an essential biosorbent to remove heavy metal ions, but the biosorption process and mechanism of different components of microbial cells have not been elucidated. In present study, Pichia pastoris X33 and $\mathrm{Cu}^{2+}$ was used as a biosorption model to reveal the biosorption process and mechanism of different components of microbial cells. For the biosorption of whole cells, the maximum removal efficiency was $41.1 \%$, and the adsorption capacity was $6.2 \mathrm{mg} \mathrm{g}^{-1}$. TEM-EDX analysis proved the existence of $\mathrm{Cu}^{2+}$ on the cell surface and cytoplasm. The maximum $\mathrm{Cu}^{2+}$ removal efficiency of the cell wall, cell membrane and cytoplasm were $21.2 \%, 20.7 \%$ and $18.5 \%$, respectively. The optimum $\mathrm{pH}$ of $\mathrm{Cu}^{2+}$ biosorption of the $P$. pastoris cell, cell wall, cell membrane and cytoplasm was 6 . Moreover, the maximum adsorption capacity of the cell, cell wall, cell membrane and cytoplasm was $16.13,11.53,10.97$ and $8.87 \mathrm{mg} \mathrm{g}^{-1}$, respectively. The maximum removal efficiencies of $P$. pastoris biomass treated with proteinase $K$ and $P$. pastoris biomass treated with $\beta$-mannanase were $18.1 \%$ and $28.2 \%$, respectively. The maximum removal efficiencies of mannan and glucan were $34 \%$ and $12 \%$, respectively. The FTIR spectra showed that the amino group $(\mathrm{N}-\mathrm{H})$, hydroxyl $(\mathrm{O}-\mathrm{H})$, carbon oxygen bond $(\mathrm{C}-\mathrm{O}),-\mathrm{CH}, \mathrm{C}-\mathrm{N}$ and carbonyl group $(\mathrm{C}=\mathrm{O})$ of a ketone or aldehyde may interact with $\mathrm{Cu}^{2+}$. Thus, our work provides guidance for further understanding the effect of different cell components on biosorption.

\section{Introduction}

With the development of industrialization, agricultural activities, and other human activity, various kinds of produced heavy metals have been discharged into water, water resources have been seriously polluted. ${ }^{\mathbf{1}, 2}$ Heavy metal contamination has been the focus for a long time due to its high toxicity and the difficulty of removal..$^{3-7}$

Many efforts have been made to find a way to effectively reduce and remove heavy metals before waste water is discharged into the environment, such as ion exchange, ${ }^{8}$ chemical precipitation, ${ }^{\mathbf{C}}$ evaporation, flotation, membrane filtration, ${ }^{\mathbf{1 0}}$ electrochemical, ${ }^{\mathbf{1 1}}$ coagulation-flocculation, and biosorption. ${ }^{\mathbf{1 2}}$ Although these technologies have proven effective, the sustainability and economic cost was hard to be underestimated. ${ }^{13}$ Biosorption, which mainly used the organisms as adsorbents, may be an alternative owing to strong adaptability, low cost, no secondary pollution, low energy consumption and

${ }^{a}$ School of Minerals Processing and Bioengineering, Central South University, Changsha, 410083, Hunan, China. E-mail: xgchencsuft@163.com; 1689256864@qq. com; zhouhb@csu.edu.cn; 443284336@qq.com

${ }^{b}$ Key Laboratory of Biometallurgy of Ministry of Education, Changsha 410083, China ${ }^{c}$ Hunan Flag Bio-Tech Co., Ltd, Changsha, Hunan, 410083, China. E-mail: xugang55@ hotmail.com high efficiency. A large quantity of studies indicated that many organisms can efficiently adsorb heavy metal ions such as soybean meal waste, sugarcane bagasse, fungi and bacteria. ${ }^{\mathbf{1 4}}$ However, most studies have only studied the biosorption properties of microbial intact cells, and limited reports have discussed the effects of microbial cell components on the biosorption process. Exploring the biosorption process and mechanism of different components of cells is very important for understanding biosorption. ${ }^{15}$

Element of $\mathrm{Cu}$ is a necessary element for biological growth. However, high concentrations of $\mathrm{Cu}$ are harmful to organisms. ${ }^{16-19}$ Excessive intake of $\mathrm{Cu}^{2+}$ leads to copper poisoning, diarrhea, epigastric pain, nausea and vomiting. Severe cases can lead to gastrointestinal mucosal ulcers, kidney damage, hemolysis, liver necrosis, shock, and even death. ${ }^{20}$ Therefore, the World Health Organization (WHO) have recommended copper concentration in drinking water not to exceed $1.3 \mathrm{mg} \mathrm{L}{ }^{-1} \cdot{ }^{21}$ However, copper is widely used in industrial productions such as electroplating, alloy manufacturing, refining processes and surface treatment industry, which inevitably resulted in the seriously pollution in water. ${ }^{15,22-26}$ Therefore, copper pollution is an urgent problem to be solved in heavy metal pollution, and the use of $\mathrm{Cu}^{2+}$ as the biosorption model of this study has certain representativeness. 
Yeast, a traditional model fungus, is commonly used in genetic engineering and fermentation engineering. ${ }^{27}$ As a result, large quantities of waste yeast produced during these processes. Commonly, waste yeast biomass was used as organic fertilizer and feed..$^{28}$ Recently, consideration of yeast as an inexpensive biosorbents for the removal of metal ions becomes the focus. ${ }^{29}$ The reason is there are many advantages of yeast, such as largescale cultivation, low safety risks and easy to use. ${ }^{15,30}$ Many studies have studied the biosorption characteristics of yeast. Chen Can studied the morphological changes of Saccharomyces cerevisiae before and after biosorption of $\mathrm{Ag}^{+} \cdot{ }^{31} \mathrm{M}$. Fadel explored the biosorption properties and optimum biosorption conditions of Saccharomyces cerevisiae for biosorption of manganese ions. ${ }^{32}$ Furthermore, Yunsong Zhang produced a bifunctional Saccharomyces cerevisiae as an adsorbent for $\mathrm{Cd}^{2+}$ or $\mathrm{Pb}^{2+}$ removal from aqueous solution. ${ }^{33}$ Fatemeh Elahian demonstrated that the genetically modified Pichia pastoris is a cost-effective, high-throughput, robust, and facile system for metal biosorption. ${ }^{34}$

All the above reports showed that yeast is an excellent and widely used adsorbent. However, the biosorption process is still unknown. Pichia pastoris was a typical model adsorbent, the exploration of the biosorption mechanism of different cell component can also provide a theoretical basis for understanding the biosorption mechanism of other adsorbents.

Here, Pichia pastoris $\mathrm{X} 33$ and $\mathrm{Cu}^{2+}$ were used as biosorption model. The biosorption process and mechanisms of Pichia pastoris were investigated. Firstly, through focusing on biosorption process of $\mathrm{Cu}^{2+}$ by Pichia pastoris biomass, the biosorption stage of $\mathrm{Cu}^{2+}$ by Pichia pastoris biomass was revealed. In addition, the relative biosorption ability of the main components of cell (cell wall, cell membrane and cytoplasm) and cell wall (glucan, protein, $\beta$-mannan) to $\mathrm{Cu}^{2+}$ was determined. Finally, the initial molecular mechanism of Pichia pastoris biosorption of $\mathrm{Cu}^{2+}$ was explored. Through this research we hope to provide a theoretical basis for the application of biological removal of heavy metals.

\section{Materials and method}

\subsection{Preparation of solution}

The copper sulphate pentahydrate was dissolved in deionized water to obtain a stock $\mathrm{Cu}^{2+}$ solution with a concentration of $400 \mathrm{mg} \mathrm{L}^{-1}$. The test solution with different concentrations was prepared by appropriately diluting the stock solution.

$2 \mathrm{~g} \mathrm{~L}^{-1}$ dicyclohexanone oxalyldihydrazone (BCO) solution: $1 \mathrm{~g}$ BCO was heated and dissolved in $400 \mathrm{~mL} \mathrm{50 \%} \mathrm{ethanol}$ solution (deionized water : ethanol $=1: 1, \mathrm{~V}: \mathrm{V}$ ). After the solution was cooled, the volume was fixed to $500 \mathrm{~mL}$.

pH 9.0 $\mathrm{NH}_{4} \mathrm{Cl}-\mathrm{NH}_{3}$ buffer: $35 \mathrm{~g}$ of $\mathrm{NH}_{4} \mathrm{Cl}$ was dissolved in appropriate deionized water, and then $24 \mathrm{~mL}$ of $15 \mathrm{~mol} \mathrm{~L}^{-1}$ ammonia water was added. Finally, the volume of the solution was determined to $500 \mathrm{~mL}$ with deionized water.

$500 \mathrm{~g} \mathrm{~L}^{-1}$ ammonium citrate solution: $250 \mathrm{~g}$ ammonium citrate was diluted to $500 \mathrm{~mL}$ with deionized water.

Proteinase K purchased from BioFroxx: enzyme activity $\geq 30$ $\mathrm{U} \mathrm{mg}^{-1}$, pH 6.2-6.8.
$\beta$-Mannanase purchased from Hunan Lerkam Biology Corp., Ltd: enzyme activity $50000 \mathrm{U} \mathrm{g}^{-1}, \mathrm{pH}$ 5.0-6.0.

Snailase purchased from Sigma-Aldrich (Shanghai) Trading Co., Ltd: pH 5.2-7.2. Hypertonic buffer: $0.8 \mathrm{~mol} \mathrm{~L}^{-1}$ mannitol prepared by phosphate buffer ( $\mathrm{pH} 6.0)$.

Pre-treatment agent: $0.1 \mathrm{~g}$ EDTA- $\mathrm{Na}_{2}$ and $0.1 \mathrm{~mL} \beta$-mercaptoethanol was dissolved in $100 \mathrm{~mL}$ deionized water. $2 \%$ SDS buffer: $2 \mathrm{~g}$ sodium dodecyl sulfate (SDS) was dissolved in $100 \mathrm{~mL}$ deionized water.

pH 2.0-8.0 $\mathrm{Na}_{2} \mathrm{HPO}_{4}$-citric acid buffer: different volumes of $0.2 \mathrm{~mol} \mathrm{~L}^{-1} \mathrm{Na}_{2} \mathrm{HPO}_{4}$ and $0.1 \mathrm{~mol} \mathrm{~L}^{-1}$ citric acid were dissolved to obtain different $\mathrm{pH}$ buffers. Different concentrations and $\mathrm{pH}$ of $\mathrm{Cu}^{2+}$ were prepared by dissolving copper sulphate pentahydrate in this buffer.

\subsection{Preparation of biosorbents}

Pichia pastoris X33 was acquired from Hunan Flag Bio-Tech Co., Ltd. It was preserved in Yeast Extract Peptone Dextrose (YPD) medium at $4{ }^{\circ} \mathrm{C}$. Cells were cultivated in liquid YPD medium using a rotating incubator at $250 \mathrm{rpm}$ and $30{ }^{\circ} \mathrm{C}$ for $12 \mathrm{~h}$, the $P$. pastoris cells were harvested by centrifugation at $7000 \mathrm{rpm}$ for 10 min. Each part of cells was obtained according to the following steps.

Cell wall: $0.5 \mathrm{~g}$ wet $P$. pastoris X33 biomass were suspended by $20 \mathrm{~mL}$ deionized water, frozen $1 \mathrm{~h}$ at $-80{ }^{\circ} \mathrm{C}$ and thawed at room temperature. The above procedure was repeated 3 times to slightly break the $P$. pastoris cells. Then ultrasonic cell-break was carried out using a JY92-IIN ultrasonic cell breaker (SCIENTZ, China) under ice bath conditions. The cells were broken repeatedly until intact cells were failed to be identified by microscopy. Then, let the broken cell suspension centrifuged $10000 \mathrm{rpm}$ for $15 \mathrm{~min} .^{35,36}$ The broken cell suspension was then divided into two parts, the precipitation was the cell wall and the membrane, the supernatant was the cytoplasm. In order to remove the cell membrane mixed in the cell wall, the precipitation was extracted by boiling water bath with $20 \mathrm{~mL} 2 \%$ SDS buffer for $1 \mathrm{~h}$ and then washed with deionized water (10 $000 \mathrm{rpm}, 15 \mathrm{~min}$ ) until the supernatant was clarified. The final precipitation was collected as the cell wall. ${ }^{37,38}$

Cell membrane and cytoplasm: $0.5 \mathrm{~g}$ wet $P$. pastoris $\mathrm{X} 33$ biomass were firstly suspended $30 \mathrm{~min}$ at $30{ }^{\circ} \mathrm{C}$ by $5 \mathrm{~mL}$ pretreatment agent. Then, the $0.5 \mathrm{~g}$ wet $P$. pastoris X33 biomass which was treated by the pre-treatment agent were washed 2 times by hypertonic buffer (7000 rpm, $5 \mathrm{~min}$ ). Next, $5 \mathrm{~mL} 2 \%$ snailase solution was added to the $0.5 \mathrm{~g}$ wet $P$. pastoris X33 biomass, and the mixture which contained $P$. pastoris $\mathrm{X} 33$ biomass and snailase was then oscillated for $6 \mathrm{~h}$ in the rotary shaker. After these steps, the mixture was washed with hypertonic buffer for 2 times to obtain protoplasts. $4 \mathrm{~mL}$ deionized water was added to the protoplasts to break the protoplasts. After that, the break protoplasts were centrifuged at $10000 \mathrm{rpm}$ for $15 \mathrm{~min}$. Consequently, the precipitation was the cell membrane, the supernatant was the cytoplasm.

$P$. pastoris treated with enzymes: $0.5 \mathrm{~g}$ wet $P$. pastoris $\mathrm{X} 33$ biomass were suspended $30 \mathrm{~min}$ at $30{ }^{\circ} \mathrm{C}$ by pre-treatment agent and then the $0.5 \mathrm{~g}$ wet $P$. pastoris $\mathrm{X} 33$ biomass which was treated by 
the pre-treatment agent were washed 2 times by hypertonic buffer (7000 rpm, $5 \mathrm{~min}$ ), after that, the $0.5 \mathrm{~g}$ wet $P$. pastoris X33 biomass were treated 6 hours with $2 \% \beta$-mannase and $2 \%$ protease $\mathrm{K}$, respectively. Finally, $P$. pastoris biomass that treated with enzymes was harvested by centrifugation at $7000 \mathrm{rpm}$ for $10 \mathrm{~min}$.

\subsection{Biosorption studies}

Unless otherwise noted, the biosorption experiments were carried out with $20 \mathrm{~mL}$ system $\left(20 \mathrm{~mL}\right.$ of $100 \mathrm{mg} \mathrm{L}^{-1} \mathrm{Cu}^{2+}$ and $0.5 \mathrm{~g}$ of wet biosorbents). Besides, the biosorption experiments were carried out on a mechanical shaker at $180 \mathrm{rpm}, 25^{\circ} \mathrm{C} .1 \mathrm{~mL}$ samples were taken out at 5, 10, 15, 30, 60, 90, 120, 150 and $180 \mathrm{~min}$. Samples were then centrifuged at $10000 \mathrm{rpm}$ for $5 \mathrm{~min}$ immediately to separate the biosorbents. After that, the supernatant was analyzed for residual $\mathrm{Cu}^{2+}$ concentration in the solution by spectrophotometry.

The procedure of spectrophotometric determination of $\mathrm{Cu}^{2+}$ concentration was as follows. Preparation of standard curve: transfer $0.0 \mathrm{~mL}, 0.2 \mathrm{~mL}, 0.4 \mathrm{~mL}, 0.8 \mathrm{~mL}, 1.2 \mathrm{~mL}, 1.6 \mathrm{~mL}, 2.0 \mathrm{~mL}$ and $2.4 \mathrm{~mL}$ of $\mathrm{Cu}^{2+}$ solution $\left(10 \mathrm{mg} \mathrm{L}^{-1}\right)$ into 8 colorimetric tubes, add $200 \mu \mathrm{L}$ ammonium citrate solution, $500 \mu \mathrm{L} \mathrm{NH}_{4} \mathrm{Cl}-\mathrm{NH}_{3}$ buffer, $500 \mu \mathrm{L} \mathrm{BCO}$, and then add deionized water to $5 \mathrm{~mL}$. Finally, the concentration of $\mathrm{Cu}^{2+}$ in the solution was analyzed using an Epoch UV-vis spectrophotometer (BioTek Inc, USA) at the wave length of $600 \mathrm{~nm}$. The formula of standard curve was as follows:

$$
y=50.791 x+0.0559, R^{2}=0.9992
$$

where, $y$ was the absorbance at $600 \mathrm{~nm}, x$ was the mass of $\mathrm{Cu}^{2+}$, mg. The $\mathrm{Cu}^{2+}$ concentration of the sample was also measured by the same method.

However, it is difficult to separate mannan, cytoplasm and glucan from $\mathrm{Cu}^{2+}$ solution by centrifugation. Therefore, the cytoplasm, glucan and mannan were injected into the dialysis bag respectively $\left(\mathrm{Cu}^{2+}\right.$ could pass through the dialysis bag and the cytoplasm, glucan, mannan could not pass through the dialysis bag). Then put the dialysis bag into the $20 \mathrm{~mL} 100 \mathrm{mg}$ $\mathrm{mL}^{-1}$ (final concentration) $\mathrm{Cu}^{2+}$ solution. Finally, the biosorption experiment was carried. The experiment of different $\mathrm{pH}$ on the biosorption was also the same as above, only the $100 \mathrm{mg} \mathrm{g}^{-1} \mathrm{Cu}^{2+}$ was replaced with different $\mathrm{pH} 100 \mathrm{mg} \mathrm{g}^{-1}$ $\mathrm{Cu}^{2+}$. After $180 \mathrm{~min}$, the concentration of $\mathrm{Cu}^{2+}$ was determined.

The $\mathrm{Cu}^{2+}$ biosorption capacity $(q)(2)$ and removal efficiency $(R)$ (1) were calculated through the following equations, respectively:

$$
\begin{gathered}
R(\%)=\frac{C_{0}-C}{C_{0}} \times 100 \% \\
q\left(\mathrm{mg} \mathrm{g}^{-1}\right)=\left(C_{0}-C\right) \times \frac{V}{m}
\end{gathered}
$$

where, $q$ (biosorption capacity) was the quantity of $\mathrm{Cu}^{2+}$ that be absorbed by the adsorbent per gram $\left(\mathrm{mg} \mathrm{g}^{-1}\right), V$ was the total volume of $\mathrm{Cu}^{2+}$ solution (L), $R$ (removal efficiency) was proportion of $\mathrm{Cu}^{2+}$ adsorbed by $P$. pastoris to total $\mathrm{Cu}^{2+} . C$ and $C_{0}$ were the residual and initial concentrations of $\mathrm{Cu}^{2+}$, respectively. And $m$ was the weight of biosorbents $(\mathrm{g})$.

\subsection{Isotherm studies}

Biosorption equilibrium isotherms were performed in Erlenmeyer flasks with $0.5 \mathrm{~g}$ of dried biosorbents in $100 \mathrm{~mL}$ of a solution of $\mathrm{Cu}^{2+}$ at different concentrations $\left(50 \mathrm{mg} \mathrm{L}^{-1}\right.$, $100 \mathrm{mg} \mathrm{L}^{-1}, 150 \mathrm{mg} \mathrm{L}^{-1}, 200 \mathrm{mg} \mathrm{L}^{-1}$ and $250 \mathrm{mg} \mathrm{L}^{-1}$ ) and agitated at $180 \mathrm{rpm}$ for $3 \mathrm{~h}$ in a shaker at $25^{\circ} \mathrm{C}$. Langmuir eqn (3) and Freundlich eqn (4) models were utilized to describe and evaluate the experimental data..$^{39,40}$

Langmuir model:

$$
\frac{C_{\mathrm{e}}}{q_{\mathrm{e}}}=\frac{1}{q_{\mathrm{m}}} C_{\mathrm{e}}+\frac{1}{q_{\mathrm{m}} b}
$$

Freundlich model:

$$
\ln q_{\mathrm{e}}=\ln K_{\mathrm{F}}+\frac{1}{n} \ln C_{\mathrm{e}}
$$

where, $q_{\mathrm{e}}$ was the equilibrium adsorption capacity of $\mathrm{Cu}^{2+}(\mathrm{mg}$ $\left.\mathrm{g}^{-1}\right), q_{\mathrm{m}}$ was the theoretical maximum adsorption capacity of $\mathrm{Cu}^{2+}\left(\mathrm{mg} \mathrm{g}^{-1}\right), C_{\mathrm{e}}$ was the $\mathrm{Cu}^{2+}$ concentration $\left(\mathrm{mg} \mathrm{L}^{-1}\right), C_{0}$ was the initial $\mathrm{Cu}^{2+}$ concentration $\left(\mathrm{mg} \mathrm{L^{-1 }}\right), b$ was Langmuir constant $\left(\mathrm{L} \mathrm{mg}{ }^{-1}\right) ; K_{\mathrm{F}}$ was the Freundlich constant which represents the adsorption capacity, and $n$ was the Freundlich equation constant.

\subsection{Analytic methods}

Transmission electron micrograph (TEM) and energy dispersive X-ray spectroscopy (EDX) experiments (TEM-EDX) were performed on a Tecnai G2 20S-Twin transmission electron microscope (FEI Czech Republic s. r. o, Czech) and a GENES XM60S Energy Dispersive Spectrometer (EDAX Inc, USA). The functional groups of the biosorbents were determined using a spectrum two Fourier transform infrared spectroscopy (PerkinElmer, UK). FTIR spectroscopy was carried out in the infrared region ranging from $4000 \mathrm{~cm}^{-1}$ to $450 \mathrm{~cm}^{-1}$. The spectra for before and after biosorption of the prepared adsorbents in the previous step were compared.

\section{Results and discussion}

\subsection{Biosorption of $\mathrm{Cu}^{2+}$ by $P$. pastoris biomass}

The removal efficiency $(R)$ of $\mathrm{Cu}^{2+}$ by $P$. pastoris increased with increasing contact time (Fig. 1). In the first place, the removal percent of $\mathrm{Cu}^{2+}$ by $P$. pastoris rose sharply in first $5 \mathrm{~min}$. After that, it rose slowly within $15 \mathrm{~min}$. The biosorption equilibrium was established at $15 \mathrm{~min}$ and the maximum removal efficiency was $41.1 \%$. However, no dramatic increase of removal efficiency was observed with a further extension of contact time (>15 min). Further observation showed that the maximum biosorption capacity $(q)$ was $1.10 \mathrm{mg} \mathrm{g}^{-1}$ (6.2 $\mathrm{mg} \mathrm{g}^{-1}$ for dry biomass), which was similar to the reported results (Fig. 1). ${ }^{41}$

Based on above results, it is suggested that there were two steps for $\mathrm{Cu}^{2+}$ biosorption: the first fast step lasted for $15 \mathrm{~min}$ (short time) and the second slow stage (long time) lasted until the equilibrium was established. ${ }^{23,42}$ It indicated that the biosorption of $\mathrm{Cu}^{2+}$ on the cell surface played an important role in 


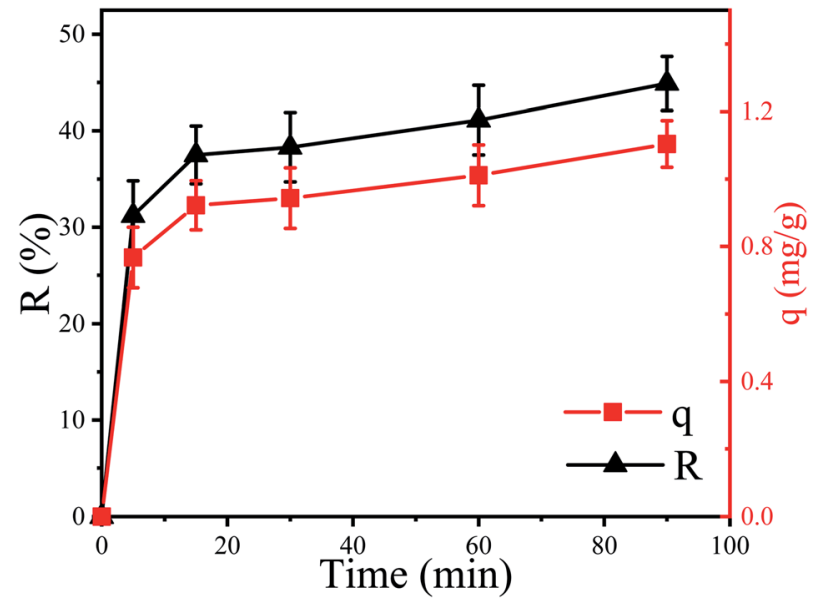

Fig. 1 Biosorption of $\mathrm{Cu}^{2+}$ by $P$. pastoris biomass, initial $\mathrm{Cu}^{2+}$ concentration: $100 \mathrm{mg} \mathrm{L}^{-1}$, wet biomass dosage: $0.5 \mathrm{~g}, R$ - removal efficiency, $q$ - biosorption capacity.

the initial biosorption process. This was because a variety of macromolecules constitute the cell wall of fungi, including mannans, proteins, glucans, lipids, etc. ${ }^{43}$ These complex macromolecular structures provide potential binding sites for many different organic and inorganic molecules. ${ }^{44}$ To sum up, it was speculated that $\mathrm{Cu}^{2+}$ was firstly adsorbed on the cell surface and then slowly entered the cell.

\subsection{TEM-EDX analysis}

To confirm that $\mathrm{Cu}^{2+}$ was firstly adsorbed on the cell surface and then slowly entered the cell, TEM-EDX experiments were performed. The TEM observation revealed that white irregular shaped precipitates $\left(\mathrm{Cu}^{2+}\right)$ were accumulated in the cytoplasm (Fig. 2A and D). Additionally, the locations and shapes of these precipitates were different (Fig. $2 \mathrm{~A}$ and $\mathrm{D}$, which was in line with prior results. ${ }^{45}$ Therefore, we could preliminarily infer that $\mathrm{Cu}^{2+}$ entered the cell and distributed unevenly. Elemental mapping clearly revealed the distribution of $\mathrm{Cu}^{2+}$ in the cells (Fig. 2B). The purple dot corresponded to $\mathrm{Cu}^{2+}$ formed the shape of a cell (red circle) and was correlated with the brightness of Fig. 2A. In addition, the number of purple dots in the green circle increases significantly. The results indicated that $\mathrm{Cu}^{2+}$ was exactly entered into the $P$. pastoris cell.

TEM-EDX further confirmed that $\mathrm{Cu}^{2+}$ was adsorbed on the cell surface and inside. Six curves in Fig. $2 \mathrm{C}$ represented the abundance of $\mathrm{C}, \mathrm{O}, \mathrm{Na}, \mathrm{S}, \mathrm{Cl}, \mathrm{Cu}$ elements from top to bottom. When the white line passed through the cell from the upper left to the lower right, the curves changed from left to right representing the change of element abundance. It could be seen that the white line entered the cell, the abundance of $\mathrm{Cu}^{2+}$ increased slightly. Then, the white line continued downward to the right, and entered the white precipitate. At this time, the abundance of $\mathrm{Cu}^{2+}$ was greatly improved. Moreover, when white lines passed through the white precipitates, the abundance of $\mathrm{Cu}^{2+}$ decreased dramatically. Finally, the white line passed through

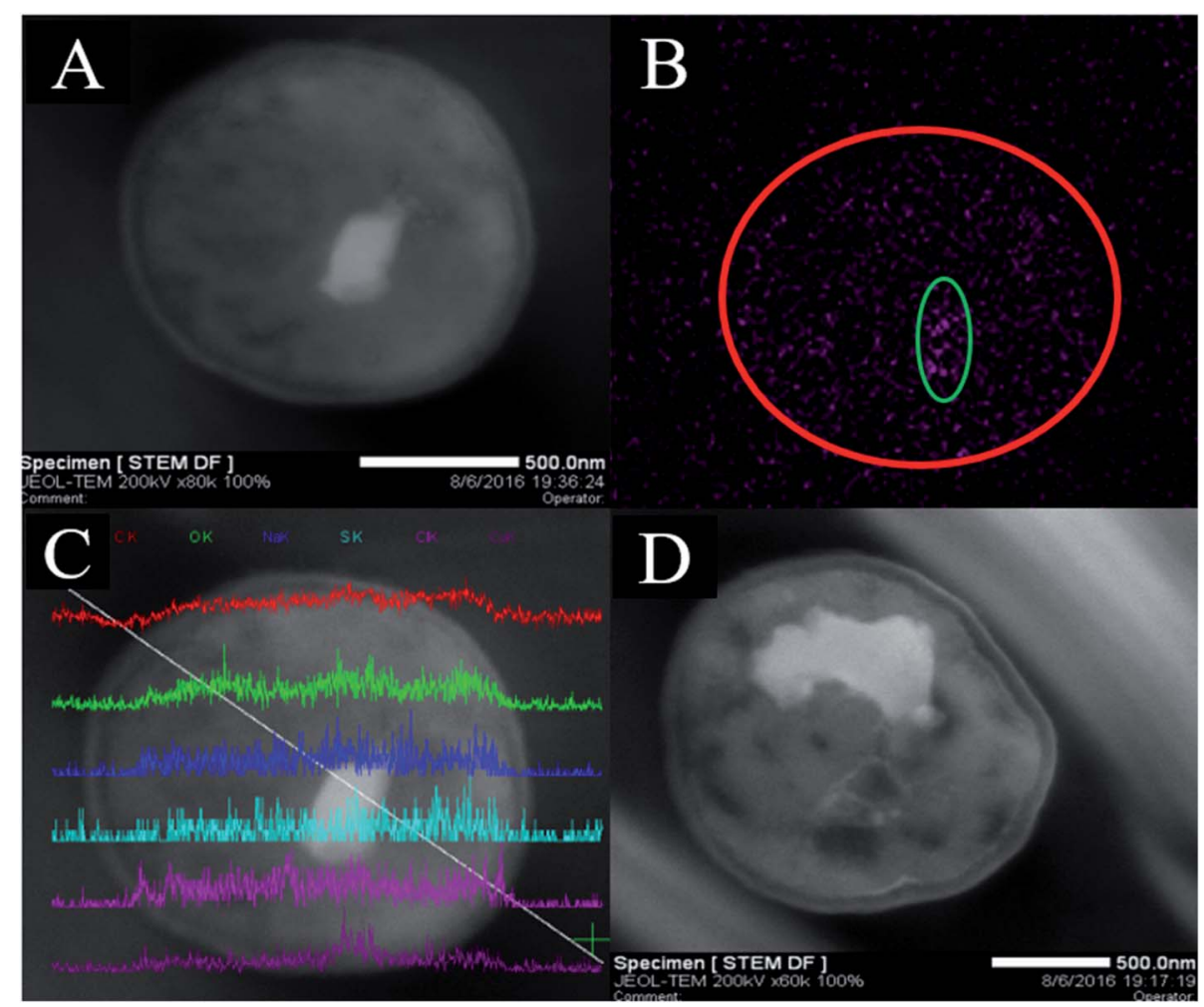

Fig. 2 TEM-EDX analyses of $\mathrm{Cu}^{2+}$-loaded $P$. pastoris biomass after exposure to $100 \mathrm{mg} \mathrm{L}^{-1} \mathrm{Cu}^{2+}$ for 1500 min, (A) TEM images of thin section of $\mathrm{Cu}^{2+}$-loaded $P$. pastoris cell; (B) elemental mapping of $\mathrm{Cu}^{2+}$-loaded $P$. pastoris cell, (C) line scan of $\mathrm{Cu}^{2+}$-loaded $P$. pastoris cell; (D) TEM images of thin section of $\mathrm{Cu}^{2+}$-loaded P. pastoris biomass. 
the cell, the abundance of $\mathrm{Cu}^{2+}$ decreased. Above evidences indicated that $\mathrm{Cu}^{2+}$ existed in the interior and surface of Pichia pastoris cell. Previous studies based on scanning electron microscopy (SEM) and EDX analysis also indicated that heavy metal ions could be adsorbed on the surface of cells. ${ }^{\mathbf{4 6}}$

Therefore, biosorption and TEM-EDX experiments further explained that biosorption was carried out in two steps. Firstly, $\mathrm{Cu}^{2+}$ bound to functional groups on cell surface by ionexchange or electrostatic interaction. ${ }^{47,48}$ Subsequently, $\mathrm{Cu}^{2+}$ passed through different layers of the cell wall (glucan, mannan and protein), then transported into the cell membrane, and eventually binds to the cytoplasm.

\subsection{Biosorption of $\mathrm{Cu}^{2+}$ by $\boldsymbol{P}$. pastoris cell components}

The results of TEM-EDX showed that $\mathrm{Cu}^{2+}$ could be adsorbed on cell surface and cytoplasm. Nevertheless, the influence of the different components of the cell on the biosorption was not clear. Consequently, the biosorption experiments of different components of cells were carried out. It was observed that the maximum $\mathrm{Cu}^{2+}$ removal efficiency of cell wall, cell membrane and cytoplasm were $21.2 \%, 20.7 \%$ and $18.5 \%$ at $45 \mathrm{~min}$, indicated that the maximum removal efficiency of cell wall was found to be slightly higher as compared to cell membrane and cytoplasm, respectively. Furthermore, it was found that the equilibrium time of the cell and cytoplasm was $30 \mathrm{~min}$, while the equilibrium time of the cell wall and cell membrane was 15 min, which further proved that the cell wall and cell membrane on the cell surface have a significant impact on the initial stage of biosorption (Fig. 3). The reason was supposed that cell disruption increased the contact area with $\mathrm{Cu}^{2+}$, cytoplasm, cell wall and cell membrane were not arranged neatly, so that the cytoplasm was exposed to the outside. E. Lopez Errasquin also believed that degraded cells, due to the destruction of cell membranes, provide more surface binding sites, greater available surface areas and expose intracellular components. ${ }^{49}$ However, the maximum removal rate of $\mathrm{Cu}^{2+}$ by cell wall, cell membrane and cytoplasm was lower than that of cell. The reason for this phenomenon may be that the cell components

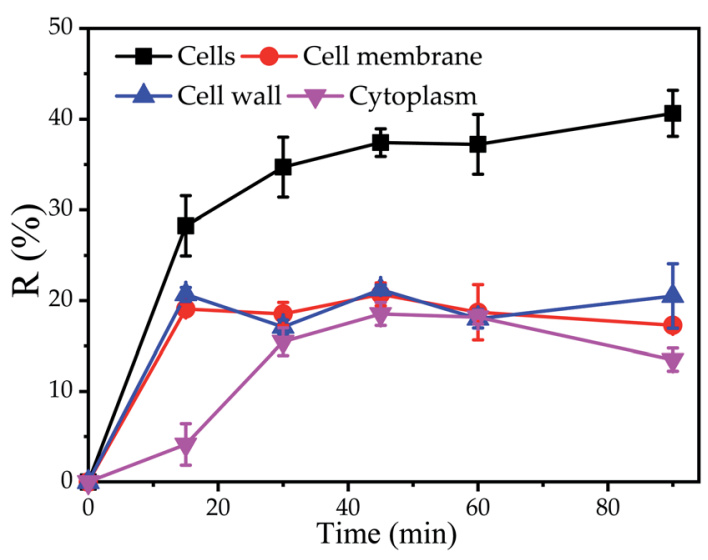

Fig. 3 Biosorption of $\mathrm{Cu}^{2+}$ by $P$. pastoris cell components, initial $\mathrm{Cu}^{2+}$ concentration: $100 \mathrm{mg} \mathrm{L}^{-1}$, wet biomass dosage: $0.5 \mathrm{~g}, R$ - removal efficiency. were prepared through a series of physical or chemical processes, such as ultrasound, Pre-treatment agent or SDS buffer, so that the cell components may lose some of the biosorption sites.

\subsection{Effect of pH on biosorption of $\mathrm{Cu}^{2+}$ by $P$. pastoris cell components}

The effect of $\mathrm{pH}$ on removal of $\mathrm{Cu}^{2+}$ by each part of cells was shown in Fig. 4. Under different $\mathrm{pH}$, the removal efficiency of $\mathrm{Cu}^{2+}$ by cells was relatively higher than that of other cell components. However, the effects of $\mathrm{pH}$ on cells and cell components were roughly the same. At lower $\mathrm{pH}$, the amount of biosorption to $\mathrm{Cu}^{2+}$ was small. Biosorption to $\mathrm{Cu}^{2+}$ increased with the increased of $\mathrm{pH}$ from 2.0 to 6.0. The highest removal efficiency was observed in the $\mathrm{pH}$ 6.0. These observations can be explained by the fact that at lower $\mathrm{pH}$ values, the surface charge of the biomass is positive, which is not favorable to cations biosorption. Meanwhile, hydrogen ions compete strongly with $\mathrm{Cu}^{2+}$ at the active sites, resulting in less biosorption. With increasing $\mathrm{pH}$, electrostatic repulsions between cations and surface sites and the competing effect of hydrogen ions decrease. Consequently, the metal biosorption increases. ${ }^{50}$ When $\mathrm{pH}$ was higher than 6 , the $\mathrm{OH}^{-}$competed with functional groups on the biosorbents to combine with $\mathrm{Cu}^{2+}$. It precipitates, and it will no longer be able to bond to the functional groups present in or on the biosorbents, leading to a decrease in its biosorption capacity as observed in this study. ${ }^{51}$

\subsection{Biosorption isotherms of $\boldsymbol{P}$. pastoris cell components}

The study of biosorption isotherm is of great significance in wastewater treatment as it provides valuable information for the pathway of biosorption reaction. In order to further explore the biosorption capacity of each cell component, the biosorption isotherm experiment was carried out. Fig. 5 showed the biosorption isotherms for intact cells, cell wall, membrane and

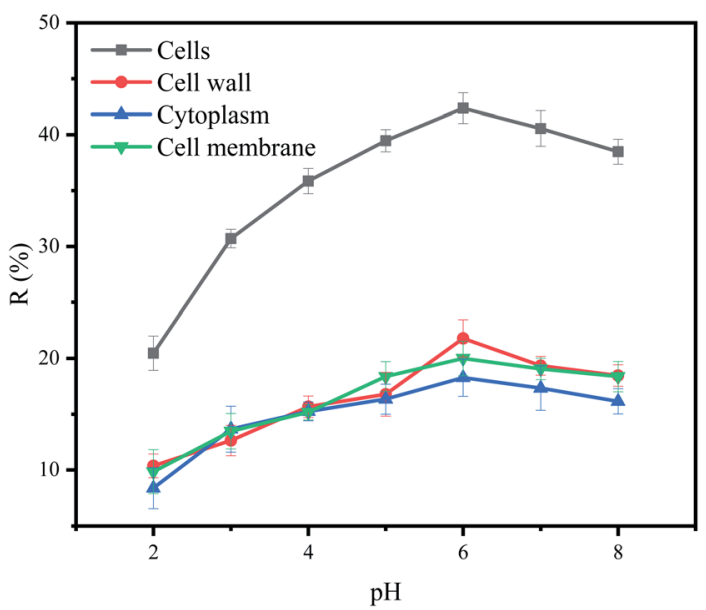

Fig. 4 Effect of $\mathrm{pH}$ on removal of $\mathrm{Cu}^{2+}$ by $P$. pastoris cell components, initial $\mathrm{Cu}^{2+}$ concentration: $100 \mathrm{mg} \mathrm{L}^{-1}$, wet biomass dosage: $0.5 \mathrm{~g}, R$ Removal efficiency, initial $\mathrm{Cu}^{2+}$ concentration: $100 \mathrm{mg} \mathrm{L}^{-1}$, wet biomass dosage: $0.5 \mathrm{~g}, R$ - removal efficiency. 

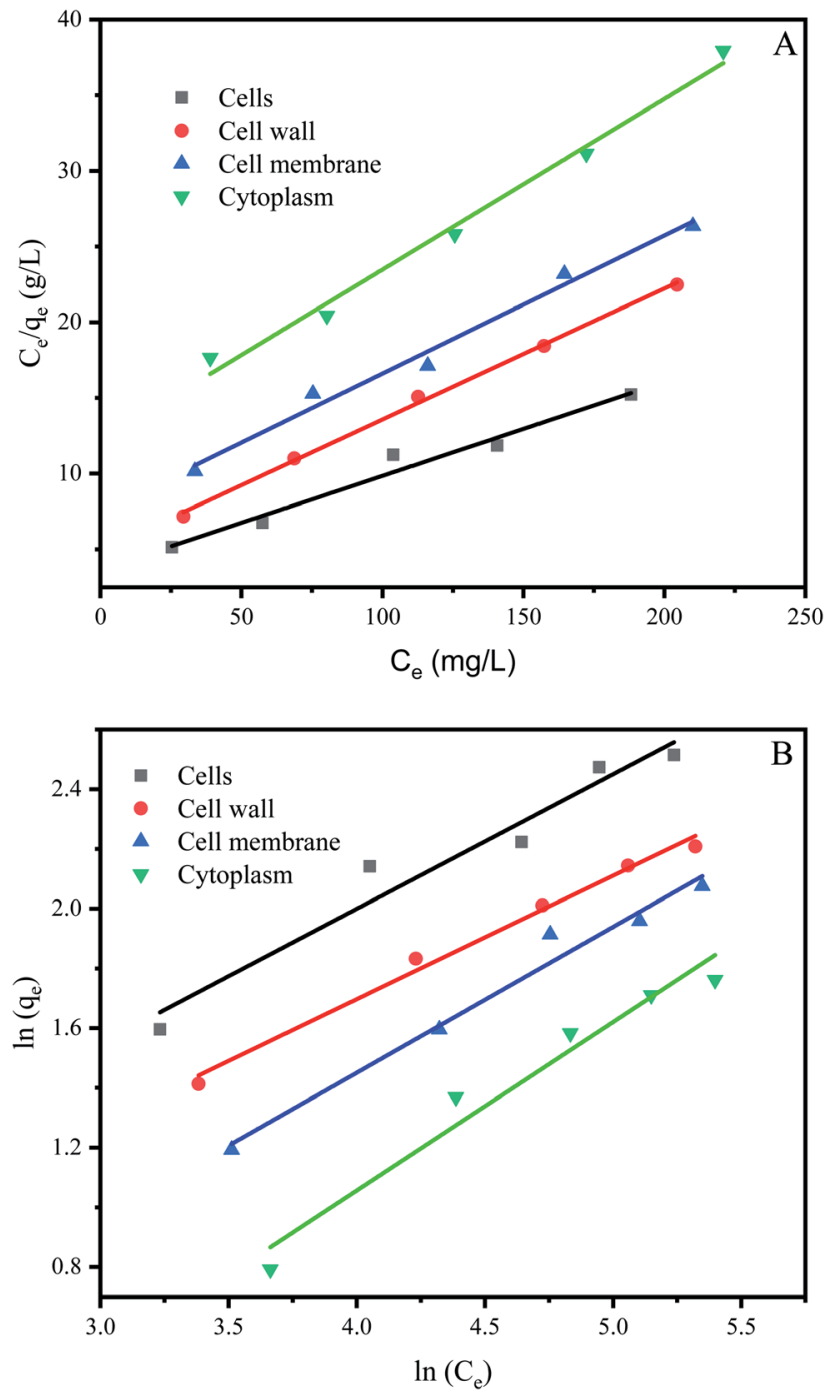

Fig. 5 Biosorption isotherms of $P$. pastoris cell components. (A) Langmuir biosorption isotherm of $\mathrm{Cu}^{2+}$ with $P$. pastoris cell components, (B) Freundlich biosorption isotherm of $\mathrm{Cu}^{2+}$ with $P$. pastoris cell components, initial $\mathrm{Cu}^{2+}$ concentration: $100 \mathrm{mg} \mathrm{L}^{-1}$, wet biomass dosage: $0.5 \mathrm{~g}, R$ - removal efficiency.

cytoplasm. All the curve-fitting parameters were summarized in Table 1. A high correlation coefficient $\left(R^{2}=0.99\right)$ indicated that Langmuir model could better fit the biosorption process of cells, cell membranes, cells and cytoplasm, while both models could fit the biosorption process of cell wall. Other studies on biosorption by yeast also observed that the biosorption equilibrium isotherm was set to the model described by Langmuir. ${ }^{51,52}$

The affinity constant $b$ obtained from the Langmuir model was 0.017 for cells, 0.018 for cell wall, 0.012 for cell membrane and 0.009 for cytoplasm, respectively (Table 1 ). Thus, cell wall has a greater affinity for $\mathrm{Cu}^{2+}$ than other cell components. This may be because the cell wall has more biosorption sites than the cell membrane and cytoplasm, in addition the cell wall has more contact area than the cell. The maximum biosorption capacity $\left(q_{\mathrm{m}}\right)$ of Pichia pastoris biomass was $16.13 \mathrm{mg} \mathrm{g}^{-1}$. The biosorption capacity of various other yeasts was measured as 2.59 to $76.8 \mathrm{mg} \mathrm{g}^{-1}$ for $\mathrm{Cu}^{2+}$ (Table 2). Table 2 indicated that
Table 1 Isotherm model parameters for biosorption of $\mathrm{Cu}^{2+}$ on $P$. pastoris cell components using Langmuir and Freundlich isotherms

\begin{tabular}{|c|c|c|c|c|c|c|}
\hline \multirow[b]{2}{*}{ Parameters } & \multicolumn{3}{|c|}{ Langmuir model } & \multicolumn{3}{|c|}{ Freundlich model } \\
\hline & $q_{\mathrm{m}}\left(\mathrm{mg} \mathrm{g}^{-1}\right)$ & $b\left(\mathrm{~L} \mathrm{mg}^{-1}\right)$ & $R^{2}$ & $K_{\mathrm{f}}\left(\mathrm{L} \mathrm{g}^{-1}\right)$ & $n$ & $R^{2}$ \\
\hline Cells & 16.13 & 0.017 & 0.97 & 1.22 & 2.22 & 0.95 \\
\hline Cell wall & 11.53 & 0.018 & 0.99 & 1.04 & 2.42 & 0.99 \\
\hline Cell membrane & 10.97 & 0.012 & 0.99 & 0.61 & 2.05 & 0.98 \\
\hline Cytoplasm & 8.87 & 0.009 & 0.99 & 0.30 & 1.77 & 0.96 \\
\hline
\end{tabular}

most yeast with strong biosorption capacity have been modified. Among the unmodified yeast, Pichia pastoris used in this study has higher biosorption capacity, indicated that Pichia pastoris is a promising biosorbent. These results agreed with previous reports that the difference species and moisture content of yeast or initial concentration of $\mathrm{Cu}^{2+}$ significant affected the removal efficiency. ${ }^{53}$ However, the maximum adsorption capacity of cell, cell wall, cell membrane and cytoplasm were $16.13,11.53,10.97$ and $8.87 \mathrm{mg} \mathrm{g}^{-1}$, respectively. Different from the rank of affinity constant $b$, the cell had the highest biosorption capacity, followed by cell wall, cell membrane and cytoplasm. This result was consistent with the result in Section 3.3, which showed that although the contact area between cells and $\mathrm{Cu}^{2+}$ was smaller than that of other cell components, the biosorption capacity of cells was still larger than that of other cell components due to the long contact time. This result also proved that the biosorption capacity of cell wall was higher than that of cell membrane and cytoplasm, which indicated that cell wall played an important role in the biosorption process.

\subsection{Effect of cell wall components of Pichia pastoris on biosorption of $\mathrm{Cu}^{2+}$}

Above results indicated that the cell wall played an important role in the initial stage of biosorption, which may be related to some material in the cell wall. The dried cell wall of yeast approximately contains $13 \%$ protein and $59.8 \%$ polysaccharide, which consist of about $31 \%$ mannan, $28.8 \%$ glucan and $8.1 \%$ of lipids. ${ }^{36,64}$ In order to investigate the effect of protein and mannan in the cell wall on biosorption, the P. pastoris biomass was treated 6 hours with $\beta$-mannanase $(50 \mathrm{U})$ and protease $\mathrm{K}(30$ $\mathrm{U})$, respectively, and then used for biosorption experiments.

Results indicated that after treatment with protease $\mathrm{K}$, the biosorption process had been greatly influenced. When the biosorption was finished, the maximum removal efficiencies of untreated $P$. pastoris biomass and treated with proteinase $\mathrm{K}$ were $43.2 \%$ and $18.1 \%$ respectively (Fig. $6 \mathrm{~A}$ ). The removal efficiency of $P$. pastoris biomass treated with proteinase $\mathrm{K}$ was only $41.9 \%$ of that in untreated P. pastoris. After treatment with $\beta$ mannanase, the removal efficiency was $28.2 \%$, accounting for $65.3 \%$ of the removal efficiency of untreated P. pastoris biomass.

It proved that protein and mannan on the cell wall played an indispensable role in the biosorption of $\mathrm{Cu}^{2+}$. Previous studies also demonstrated that $\mathrm{Cu}^{2+}$ could be adsorbed by protein which 
Table 2 Biosorption parameter of $\mathrm{Cu}^{2+}$ on other yeasts biomass

\begin{tabular}{|c|c|c|c|c|}
\hline Biosorbent & $q_{\mathrm{m}}\left(\mathrm{mg} \mathrm{g}^{-1}\right)$ & $\mathrm{pH}$ & Equilibrium time & Ref. \\
\hline Magnetically modified brewer's yeast & 76.8 & $5-7$ & $60 \mathrm{~min}$ & 54 \\
\hline EDTAD-modified baker's yeast & 65.0 & 6.0 & $20 \min$ & 55 \\
\hline Beer yeast & 20.6 & 6 & $60 \mathrm{~min}$ & 57 \\
\hline S. cerevisiae treated with $\mathrm{NaOH}$ & 20 & 4.6 & $4 \mathrm{~h}$ & 58 \\
\hline Heat pretreated baker's yeast & 19.53 & 4.5 & $30 \mathrm{~min}$ & 59 \\
\hline Baker's yeast treated with ethanol & 15.64 & 5 & $20 \mathrm{~min}$ & 56 \\
\hline S. cerevisiae & 15.1 & 3.0 & $2 \mathrm{~h}$ & 61 \\
\hline Baker's yeast & 11.53 & 5 & $20 \mathrm{~min}$ & 56 \\
\hline S. cerevisiae treated with ethanol & 9.82 & 4.6 & $4 \mathrm{~h}$ & 58 \\
\hline S. cerevisiae $-\mathrm{Fe}_{3} \mathrm{O}_{4}$ & 8.30 & 5.5 & $10 \min \times 9$ & 62 \\
\hline S. cerevisiae & 4.73 & 5 & $24 \mathrm{~h}$ & 53 \\
\hline
\end{tabular}

directly influenced photosynthesis ${ }^{65}$ and caused oxidative damage of cells. ${ }^{66}$ Misbah Saleem explored the utilization of biomass from coconut copra meal (CCM) as a biosorbent to remove $\mathrm{Ni}^{2+}$ from aqueous solutions, and the main component of coconut powder is mannan, which also proved that mannan could adsorb heavy metal ions. ${ }^{67}$ Xuegang Luo also proved that the modified mannan had excellent biosorption properties for $\mathrm{Cu}^{2+} .68$

Not only that, the removal efficiency of $\mathrm{Cu}^{2+}$ by Pichia pastoris treated with protease $\mathrm{K}$ decreased more, which indicated that the protein had a greater impact on the entire biosorption process, even if the cell wall contained more mannans. The protein then appears to be the "glue" which affixes the two wall layers together, which results in the mannan-protein layer that may be almost completely removed by protease $\mathrm{K}$, while the mannanase only removed some of the mannan and not the entire layer. ${ }^{64}$

As mentioned above, the polysaccharide content in the cell wall was $59.8 \%$, of which glucan was as high as $31 \%$. To further determine the relative biosorption capacity of glucan and mannan in the cell wall for $\mathrm{Cu}^{2+}$. Biosorption of $\mathrm{Cu}^{2+}$ by glucan and mannan was carried out.

Results indicated that the removal efficiency of mannan and P. pastoris reached $34 \%$ and $43.3 \%$, respectively (Fig. 6B). However, the removal efficiency of $\mathrm{Cu}^{2+}$ by mannan was better than that of $P$. pastoris in the early stage of biosorption which may due to that the mannan on the cell wall is a threedimensional arrangement. Therefore, at the first stage of biosorption, the groups on the cell surface combined with $\mathrm{Cu}^{2+}$. After that, the groups inside the cell functioned with the penetration of $\mathrm{Cu}^{2+}$. In contrast, all groups of the broken cell wall were exposed outside, $\mathrm{Cu}^{2+}$ can be fully contacted with the cell walls. The fact further indicated that mannan on $P$. pastoris surface also played an indispensable role in biosorption of $\mathrm{Cu}^{2+}$.

However, it was noticed that the role of glucan in the biosorption process was mediocre. When the reaction was carried out to $10 \mathrm{~min}$, the removal efficiency of glucan was $12 \%$ and desorption occurred subsequently, agreed with prior results that desorption occurs in some environments (Fig. 6B). ${ }^{69}$
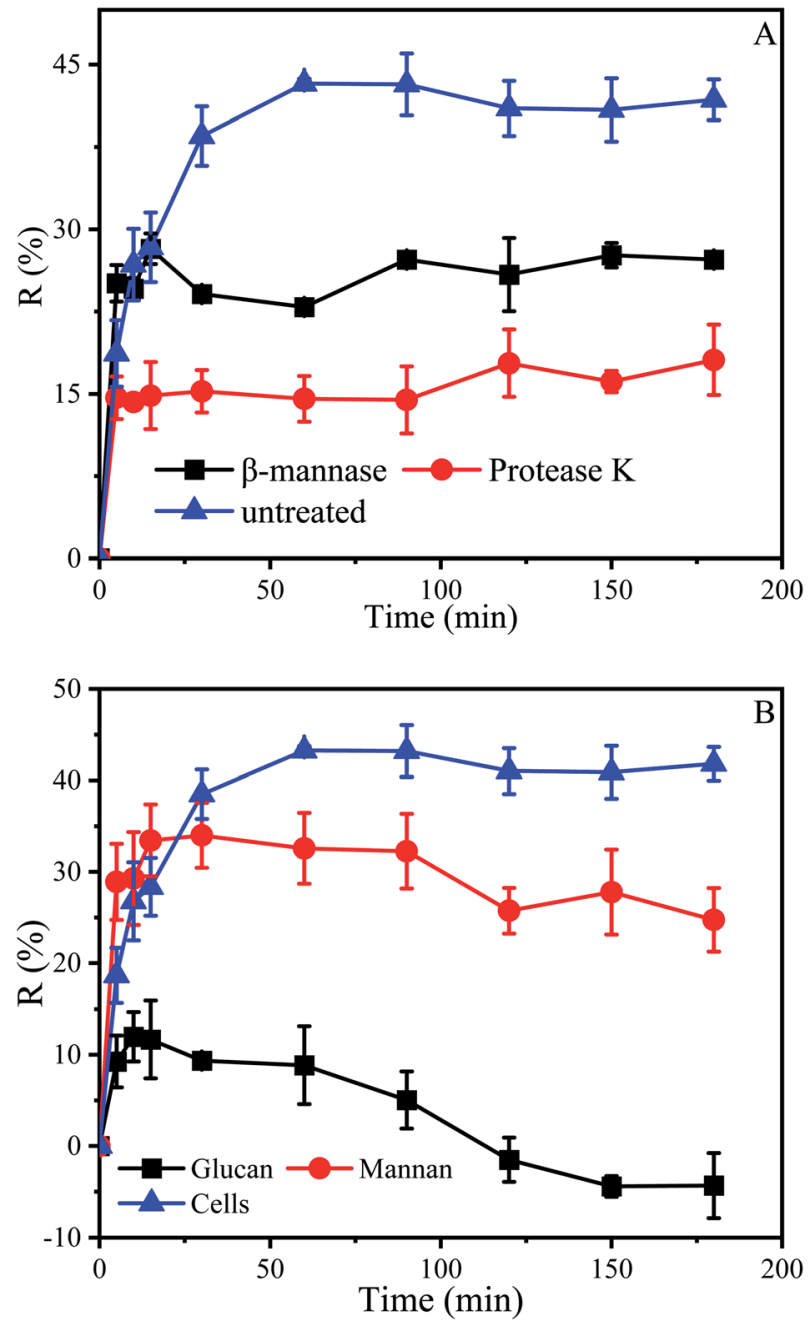

Fig. 6 Effect of cell wall components of Pichia pastoris on biosorption of $\mathrm{Cu}^{2+}$. (A) Biosorption of $\mathrm{Cu}^{2+}$ by $P$. pastoris treated with enzymes, (B) biosorption of $\mathrm{Cu}^{2+}$ by glucan and mannan, initial $\mathrm{Cu}^{2+}$ concentration: $100 \mathrm{mg} \mathrm{L}^{-1}$, wet biomass dosage: $0.5 \mathrm{~g}, R$ - removal efficiency. 
Removal efficiency is related to the properties of biosorbents, such as the amount of functional groups, molecular structure, swelling degree, surface area, and particle size. ${ }^{70}$ For instance, the basic unit of chitosan is glucosamine, which is similar to glucan in structure. However, in contrast to glucan, many reports have shown that chitosan has highly efficient adsorption of heavy metal ions. ${ }^{71}$ In addition, chitosan could be obtained by $\mathrm{N}$-deacetylation of chitin contained in yeast cell wall. This is also the reason why many studies tend to modify yeast to improve its adsorption capacity (Table 2). Mannose and glucose are isomers, which results in mannan having some functions that glucan does not have. Therefore, mannan and glucan had essential differences in structure, which was the reason for their different removal efficiency. ${ }^{72}$ These results also suggested that we could modify the mannan in the cell wall to improve the adsorption capacity of yeast, and the modification of yeast was inseparable from the exploration of adsorption sites.

\subsection{FTIR analysis}

The FTIR spectrum could effectively identify functional groups that may bind to $\mathrm{Cu}^{2+} \cdot{ }^{73-75}$ Each functional group has a specific absorption peak. When $\mathrm{Cu}^{2+}$ interacts with functional groups, the adsorption peaks of functional groups shift to higher or lower wave numbers.
Fig. 7A described the FTIR spectrum of P. pastoris biomass. The broad and intensely stretched peak at $3390 \mathrm{~cm}^{-1}$ due to the presence of hydroxyl $(\mathrm{O}-\mathrm{H})$ stretching in hydrogen bonds. After the biosorption process, the peak shifted to $3416 \mathrm{~cm}^{-1}$, indicated that the hydroxyl from polysaccharides, fatty acids and protein were involved the biosorption of $\mathrm{Cu}^{2+} \cdot 76,77$ The peaks at $2926 \mathrm{~cm}^{-1}$ and $1404 \mathrm{~cm}^{-1}$ represented the asymmetric stretching vibration of $-\mathrm{CH}_{2}$ and bending vibration of $-\mathrm{CH}_{3}$ and $-\mathrm{CH}_{2}$. After the biosorption process, the peaks became more blunter, indicated that $-\mathrm{CH}_{2}$ and $\mathrm{CH}_{3}$ were the functional group to combine with $\mathrm{Cu}^{2+}$. Sławomir Wierzba also found that $-\mathrm{CH}_{2}$ and $\mathrm{CH}_{3}$ were the biosorption group in the yeast cell. ${ }^{78}$ The peaks observed at $1650 \mathrm{~cm}^{-1}$ was attributed to amide I band (stretching vibration of $\mathrm{C}=\mathrm{O}$ ), $1540 \mathrm{~cm}^{-1}$ indicated the amide II band (stretching vibration of $\mathrm{C}-\mathrm{N}$ and bending vibration of $\mathrm{N}-\mathrm{H}), 1248 \mathrm{~cm}^{-1}$ was attributed to amide III band (stretching vibration of $\mathrm{C}-\mathrm{N}$ and bending vibration of $\mathrm{N}-\mathrm{H}){ }^{79,80}$ After biosorption, the wavenumber shifted to $1642 \mathrm{~cm}^{-1}, 1546 \mathrm{~cm}^{-1}, 1244 \mathrm{~cm}^{-1}$ respectively, further proved that protein played an important role in the biosorption of $\mathrm{Cu}^{2+}$. The peak at $1074 \mathrm{~cm}^{-1}$ corresponded to stretching vibrations of $\mathrm{C}-\mathrm{O}$ which from polysaccharides, after biosorption, the wavenumber shifted to1076 $\mathrm{cm}^{-1} \mathbf{. 8 1}$
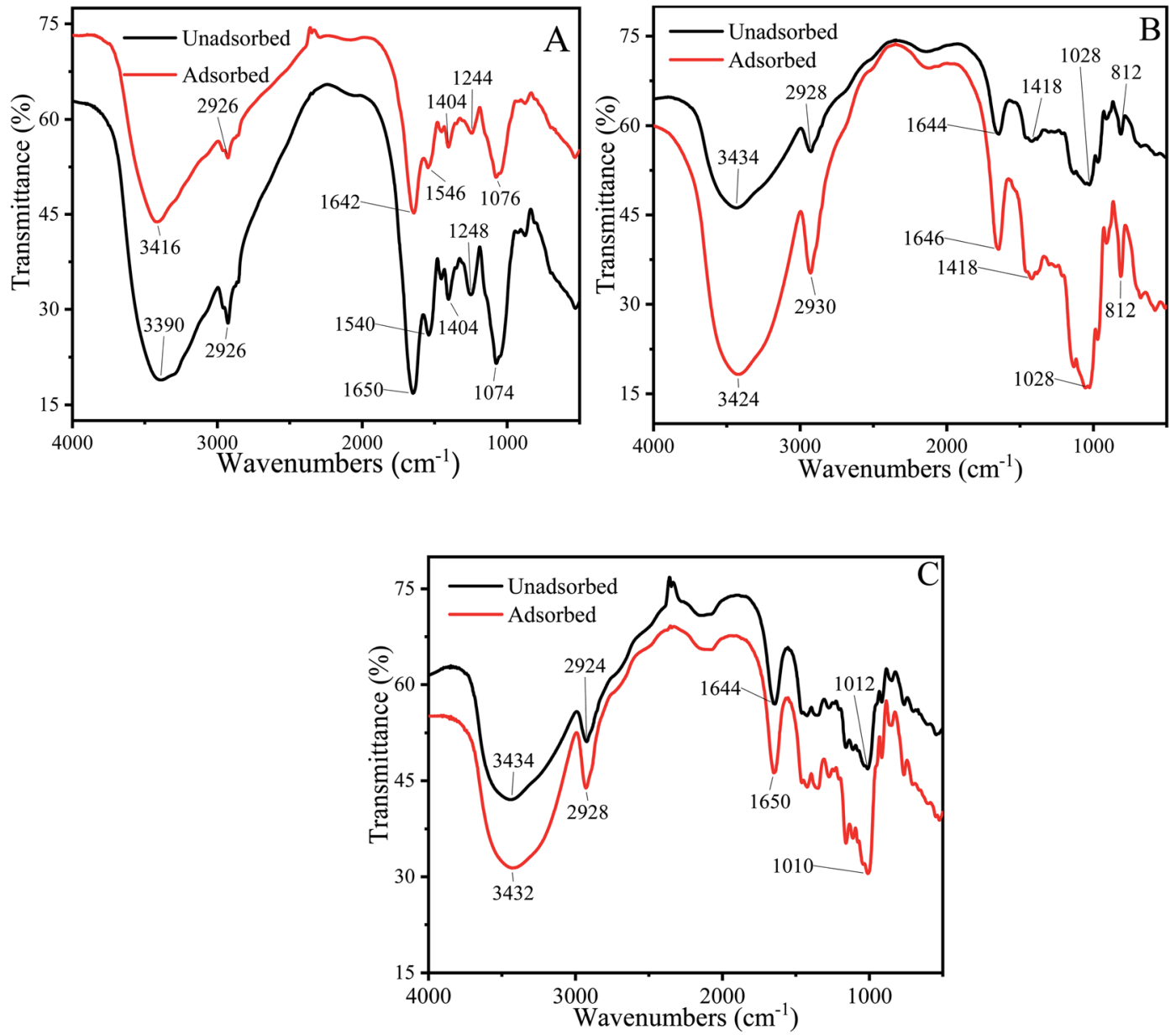

Fig. 7 FTIR spectrum of unadsorbed and $\mathrm{Cu}^{2+}$-adsorbed biosorbents. (A) $\mathrm{Cu}^{2+}$-Adsorbed and unadsorbed P. pastoris biomass. (B) $\mathrm{Cu}^{2+}$ Adsorbed and unadsorbed mannan. (C) $\mathrm{Cu}^{2+}$-Adsorbed and unadsorbed glucan. 
Above results demonstrated that $-\mathrm{OH}, \mathrm{C}-\mathrm{N}, \mathrm{N}-\mathrm{H}, \mathrm{C}=\mathrm{O}, \mathrm{C}-\mathrm{O}$ and $-\mathrm{CH}$ from protein, polysaccharides and fatty acids were involved in $\mathrm{Cu}^{2+}$ biosorption process. It was consistent with previous biosorption experiment results. Haojie Huang also found that amide II, $-\mathrm{CH}_{2}$, hydroxyl group, acetylamino group and amide I on the surface of $E$. coli cells participated in the biosorption of heavy metals. ${ }^{\mathbf{8 2}}$

To confirm the key groups of mannan and glucan to adsorb $\mathrm{Cu}^{2+}$, FTIR spectrum of mannan and glucan before and after biosorption were determined. Fig. 7B and $\mathrm{C}$ showed the groups whose peak shape changed significantly after mannan and glucan adsorbed $\mathrm{Cu}^{2+}$. Similar biosorption groups were present in glucan and mannan. However, the number of biosorption groups of mannan and glucan was significantly reduced.

Broad peak present in the $3434 \mathrm{~cm}^{-1}$ was attributed to the hydroxyl $(-\mathrm{OH})$ stretching vibrations. After biosorption process, the wavenumber shifted to $3424 \mathrm{~cm}^{-1}$ and $3432 \mathrm{~cm}^{-1}$ respectively (Fig. 7B and C). It was suggested that the hydroxyl groups on mannan and glucan could also adsorb $\mathrm{Cu}^{2+}$, which was consistent with the previous experimental results. The peaks at $2928 \mathrm{~cm}^{-1}$ and $2924 \mathrm{~cm}^{-1}$ shifted to $2930 \mathrm{~cm}^{-1}$ and $2928 \mathrm{~cm}^{-1}$ respectively (Fig. 7B and C). The peak at $1418 \mathrm{~cm}^{-1}$ was also the - $\mathrm{CH}$ stretching vibration (Fig. 7B). After the biosorption process, the peak became acuter. It could be speculated that $-\mathrm{CH}_{2}$ and $-\mathrm{CH}_{3}$ in mannan and glucan were involved in biosorption of $\mathrm{Cu}^{2+}$. Similar results were found in other adsorbents. ${ }^{77,83}$ The peak observed at $1644 \mathrm{~cm}^{-1}$ was attributed to the $\mathrm{C}=\mathrm{O}$ stretching vibration of mannan and glucan. ${ }^{\mathbf{8 4}}$ After biosorption process, the wavenumbers shifted to $1646 \mathrm{~cm}^{-1}$ and $1650 \mathrm{~cm}^{-1}$ respectively, demonstrated that $\mathrm{C}=\mathrm{O}$ in mannan and glucan could also bind to $\mathrm{Cu}^{2+}$. The peak at $1028 \mathrm{~cm}^{-1}$ was attributed to stretching vibration of $\mathrm{C}-\mathrm{O}$ (Fig. 7B). After biosorption, the peak did not change, indicated that $-\mathrm{C}-\mathrm{O}$ was not the main group to combine with $\mathrm{Cu}^{2+}$ in mannan (Fig. 7B). However, the peak at $1012 \mathrm{~cm}^{-1}$ shifted to $1010 \mathrm{~cm}^{-1}$ demonstrated that the $\mathrm{C}-\mathrm{O}$ bond in glucan could bind to $\mathrm{Cu}^{2+}$ (Fig. 7C). The peak at $812 \mathrm{~cm}^{-1}$ was attributed to pyranose ring vibration band of mannose, which did not involve the biosorption of $\mathrm{Cu}^{2+}$ (Fig. 7B). ${ }^{85}$

Above results showed that the polysaccharides on the cell wall also had a certain number of biosorption groups, which further proved the importance of polysaccharides for biosorption (Fig. 7B and C). However, when there were only polysaccharides and no protein in the cell wall, the number of biosorption sites also decreased, which also indicated the importance of protein in biosorption (Fig. 7).

The FTIR spectra indicated that $\mathrm{C}=\mathrm{O}, \mathrm{N}-\mathrm{H},-\mathrm{OH}, \mathrm{C}-\mathrm{O}, \mathrm{C}-\mathrm{N}$, and $-\mathrm{CH}$ were responsible for biosorption of $\mathrm{Cu}^{2+}$. Although the biosorption sites of mannan and glucan decreased, their biosorption sites were consistent with $P$. pastoris biomass. Many studies have reported that these similar groups can adsorb heavy metal ions. ${ }^{22,86-88}$

\section{Conclusions}

Microorganism biomass could be used as an environmentally friendly and inexpensive adsorbent for heavy meatal biosorption from wastewater. However, the effect of each component of microbial cells on the adsorption of heavy metals is still unclear. In present study, $P$. pastoris and $\mathrm{Cu}^{2+}$ were used as models to explore the adsorption capacity of different microbial cell components for heavy metal ions. The biosorption experiment with $100 \mathrm{mg} \mathrm{L}^{-1} \mathrm{Cu}^{2+}$ showed that the biosorption equilibrium time of $P$. pastoris biomass was $15 \mathrm{~min}$, the maximum removal efficiency was $41.1 \%$, and the adsorption capacity was $6.2 \mathrm{mg} \mathrm{g}^{-1}$. TEM-EDX showed that the associated $\mathrm{Cu}^{2+}$ heterogeneously present on the surface and inside of $P$. pastoris cells. These results indicated that the biosorption of $\mathrm{Cu}^{2+}$ on the cell surface played an important role in the initial biosorption process. The biosorption experiment with $100 \mathrm{mg} \mathrm{L}{ }^{-1} \mathrm{Cu}^{2+}$ indicated that the maximum $\mathrm{Cu}^{2+}$ removal efficiency of cell wall, cell membrane and cytoplasm were $21.2 \%, 20.7 \%$ and $18.5 \%$, respectively. The optimum $\mathrm{pH}$ of $\mathrm{Cu}^{2+}$ biosorption on $P$. pastoris cell, cell wall, cell membrane and cytoplasm was 6 . Moreover, the maximum adsorption capacity of cell, cell wall, cell membrane and cytoplasm were 16.13, $11.53,10.97$ and $8.87 \mathrm{mg} \mathrm{g}^{-1}$, respectively. Compared with other cell components, the adsorption capacity of cell wall was slightly higher, further indicated that cell wall played an important role in the initial biosorption process. In addition, the maximum removal efficiencies of $P$. pastoris biomass treated with proteinase $\mathrm{K}$ and $P$. pastoris biomass treated with $\beta$-mannanase were $18.1 \%$ and $28.2 \%$, respectively, indicated that biosorption of $\mathrm{Cu}^{2+}$ was strongly influenced by the protein and mannan on the cell wall. The maximum removal efficiencies of mannan and glucan were $34 \%$ and $12 \%$, respectively, indicated that the biosorption of mannan was stronger than that of glucan. Furthermore, the groups that could adsorb $\mathrm{Cu}^{2+}$ in $P$. pastoris biomass, mannan and glucan were hydroxyl $(\mathrm{O}-\mathrm{H})$, carbon oxygen bond $(\mathrm{C}-\mathrm{O}),-\mathrm{CH}, \mathrm{C}-\mathrm{N}$ and carbonyl group $(\mathrm{C}=$ O). In addition, amino group $(\mathrm{N}-\mathrm{H})$, and $\mathrm{C}-\mathrm{N}$ in $P$. pastoris biomass could also adsorb $\mathrm{Cu}^{2+}$. Finally, this study proved that in the process of heavy metal biosorption, the cell wall has the strongest adsorption capacity, and the protein and mannan in the cell wall have great influence on the biosorption due to its rich adsorption sites. The results will provide a theoretical basis for further understanding of the mechanism of biosorption of heavy metal ions. In addition, the results can provide guidance for the modification of yeast to improve its adsorption capacity.

\section{Conflicts of interest}

There are no conflicts to declare.

\section{Acknowledgements}

This work was supported by the Natural Science Foundation of Hunan Province, China (grant number 2015JJ5006); the National Natural Science Foundation of China (grant number 31870115) and the Hunan Flag Bio-Tech Co., Ltd, China.

\section{References}

1 S. J. Yu, X. X. Wang, W. Yao, et al., Macroscopic, Spectroscopic, and Theoretical Investigation for the 
Interaction of Phenol and Naphthol on Reduced Graphene Oxide, Environ. Sci. Technol., 2017, 51(6), 3278-3286.

2 I. Ali, New Generation Adsorbents for Water Treatment, Chem. Rev., 2012, 112(10), 5073-5091.

3 P. A. Xu, G. M. Zeng, D. L. Huang, et al., Adsorption of Pb (II) by iron oxide nanoparticles immobilized Phanerochaete chrysosporium: Equilibrium, kinetic, thermodynamic and mechanisms analysis, Chem. Eng. J., 2012, 203, 423-431.

4 T. Y. Jiang, J. Jiang, R. K. Xu, et al., Adsorption of Pb (II) on variable charge soils amended with rice-straw derived biochar, Chemosphere, 2012, 89(3), 249-256.

5 Y. Cheng, C. P. Yang, H. J. He, et al., Biosorption of Pb (II) Ions from Aqueous Solutions by Waste Biomass from Biotrickling Filters: Kinetics, Isotherms, and Thermodynamics, J. Environ. Eng., 2016, $142(9), 7$.

6 D. John Babu, P. King and Y. Prasanna Kumar, Optimization of $\mathrm{Cu}$ (II) biosorption onto sea urchin test using response surface methodology and artificial neural networks, Int. J. Environ. Sci. Technol., 2019, 16(4), 1885-1896.

7 M. Banerjee, R. K. Basu and S. K. Das, Cu (II) removal using green adsorbents: kinetic modeling and plant scale-up design, Environ. Sci. Pollut. Res., 2019, 26(12), 11542-11557.

8 A. Dąbrowski, Z. Hubicki, P. Podkościelny, et al., Selective removal of the heavy metal ions from waters and industrial wastewaters by ion-exchange method, Chemosphere, 2004, 56(2), 91-106.

9 L. Charerntanyarak, Heavy metals removal by chemical coagulation and precipitation, Water Sci. Technol., 1999, 39(10), 135-138.

$10 \mathrm{H}$. A. Qdais and H. Moussa, Removal of heavy metals from wastewater by membrane processes: a comparative study, Desalination, 2004, 164(2), 105-110.

11 C. Yuan and C. H. Weng, Electrokinetic enhancement removal of heavy metals from industrial wastewater sludge, Chemosphere, 2006, 65(1), 88-96.

12 S. M. Lee, C. Laldawngliana and D. Tiwari, Iron oxide nanoparticles-immobilized-sand material in the treatment of $\mathrm{Cu}(\mathrm{II}), \mathrm{Cd}(\mathrm{II})$ and $\mathrm{Pb}(\mathrm{II})$ contaminated waste waters, Chem. Eng. J., 2012, 195, 103-111.

13 B. Volesky, Detoxification of metal-bearing effluents: biosorption for the next century, Hydrometallurgy, 2001, 59(2), 203-216.

14 I. S. Bădescu, D. Bulgariu, I. Ahmad, et al., Valorisation possibilities of exhausted biosorbents loaded with metal ions - A review, J. Environ. Manage., 2018, 224, 288-297.

15 J. Wang and C. Chen, Biosorption of heavy metals by Saccharomyces cerevisiae: a review, Biotechnol. Adv., 2006, 24(5), 427-451.

16 R. Manohari and K. N. Yogalakshmi, Optimization of Copper (II) Removal by Response Surface Methodology Using Root Nodule Endophytic Bacteria Isolated from Vigna unguiculata, Water, Air, Soil Pollut., 2016, 227(8), 13.

17 A. Verma, S. A. Shalu, et al., Biosorption of $\mathrm{Cu}$ (II) using free and immobilized biomass of Penicillium citrinum, Ecol. Eng., 2013, 61, 486-490.

18 M. R. Awual, New type mesoporous conjugate material for selective optical copper (II) ions monitoring \& removal from polluted waters, Chem. Eng. J., 2017, 307, 85-94.
19 M. R. Awual, M. M. Hasan, M. A. Khaleque, et al., Treatment of copper (II) containing wastewater by a newly developed ligand based facial conjugate materials, Chem. Eng. J., 2016, 288, 368-376.

20 A. A. Al-Homaidan, H. J. Al-Houri, A. A. Al-Hazzani, et al., Biosorption of copper ions from aqueous solutions by Spirulina platensis biomass, Arabian J. Chem., 2014, 7(1), 57-62.

21 J. Cotruvo, WHO Guidelines for Drinking Water Quality: First Addendum to the Fourth Edition, J.-Am. Water Works Assoc., 2017, 109, 44-51.

22 X. J. Hu, H. D. Gu, T. T. Zang, et al., Biosorption mechanism of $\mathrm{Cu}^{2+}$ by innovative immobilized spent substrate of fragrant mushroom biomass, Ecol. Eng., 2014, 73, 509-513.

23 W. S. Wan Ngah and M. A. K. M. Hanafiah, Biosorption of copper ions from dilute aqueous solutions on base treated rubber (Hevea brasiliensis) leaves powder: kinetics, isotherm, and biosorption mechanisms, J. Environ. Sci., 2008, 20(10), 1168-1176.

24 L. X. Huang, M. L. Li, G. C. Si, et al., Assessment of microbial products in the biosorption process of $\mathrm{Cu}(\mathrm{II})$ onto aerobic granular sludge: Extracellular polymeric substances contribution and soluble microbial products release, $J$. Colloid Interface Sci., 2018, 527, 87-94.

25 D. J. Babu, P. King and Y. P. Kumar, Optimization of Cu (II) biosorption onto sea urchin test using response surface methodology and artificial neural networks, Int. J. Environ. Sci. Technol., 2019, 16(4), 1885-1896.

$26 \mathrm{~J}$. Wang and C. Chen, Biosorbents for heavy metals removal and their future, Biotechnol. Adv., 2009, 27(2), 195-226.

27 J. Vina-Gonzalez, K. Elbl, X. Ponte, et al., Functional expression of aryl-alcohol oxidase in Saccharomyces cerevisiae and Pichia pastoris by directed evolution, Biotechnol. Bioeng., 2018, 115(7), 1666-1674.

28 R. Mata, S. Ratinho and D. Fangueiro, Assessment of the Environmental Impact of Yeast Waste Application to Soil: An Integrated Approach, Waste Biomass Valorization, 2019, 10(6), 1767-1777.

29 E. Savastru, C. Zamfir and M. Diaconu, et al., Biosorption of $\mathrm{Cu}$ (II) Ions from Aqueous Solution on Saccharomyces Cerevisiae Biomass: Isotherm and Kinetics Modelling, Proceedings of the 2019 E-Health and Bioengineering Conference (EHB), Iaşi, Romania, F 21-23 Nov. 2019, 2019 [C]. EHB 2019 Grigore T, Popa University of Medicine and Pharmacy, Iași, Romania, 2019.

30 E. V. Soares and H. Soares, Bioremediation of industrial effluents containing heavy metals using brewing cells of Saccharomyces cerevisiae as a green technology: a review, Environ. Sci. Pollut. Res., 2012, 19(4), 1066-1083.

31 C. Chen, D. Wen and J. Wang, Cellular surface characteristics of Saccharomyces cerevisiae before and after $\mathrm{Ag}(\mathrm{I})$ biosorption, Bioresour. Technol., 2014, 156, 380-383.

32 M. Fadel, N. M. Hassanein, M. M. Elshafei, et al., Biosorption of manganese from groundwater by biomass of Saccharomyces cerevisiae, HBRC J., 2017, 13(1), 106-113.

33 Y. S. Zhang, W. G. Liu, L. Zhang, et al., Application of bifunctional Saccharomyces cerevisiae to remove lead(II) 
and cadmium(II) in aqueous solution, Appl. Surf. Sci., 2011, 257(23), 9809-9816.

34 F. Elahian, R. Heidari, V. R. Charghan, et al., Genetically modified Pichia pastoris, a powerful resistant factory for gold and palladium bioleaching and nanostructure heavy metal biosynthesis, Artif Cell Nanomed B, 2020, 48(1), 259265.

35 T. P. Lyons and J. S. Hough, Glycoproteins from yeast cell wall, Biochem. J., 1970, 117(2), 44P.

36 P. A. Roelofsen, Yeast mannan, a cell wall constituent of baker's yeast, Biochim. Biophys. Acta, 1953, 10(3), 477-478.

37 P. Valachovic, A. Pechova and T. J. Mason, Towards the industrial production of medicinal tincture by ultrasound assisted extraction, Ultrason. Sonochem., 2001, 8(2), 111-117.

38 Z. Hromadkova, A. Ebringerova and P. Valachovic, Comparison of classical and ultrasound-assisted extraction of polysaccharides from Salvia officinalis L, Ultrason. Sonochem., 1999, 5(4), 163-168.

39 I. Langmuir, The constitution and fundamental properties of solids and liquids, J. Am. Chem. Soc., 1916, 38(11), 2221-2295.

$40 \mathrm{H}$. Freundlich, Over the adsorption in solution, J. Phys. Chem., 1906, 57, 385-471.

41 A. Dutta, L. P. Zhou, C. O. Castillo-Araiza, et al., Cadmium (II), Lead (II), and Copper (II) Biosorption on Baker's Yeast (Saccharomyces cerevesiae), J. Environ. Eng., 2016, 142(9), 7.

42 R. Razmovski and M. Śćiban, Biosorption of $\mathrm{Cr}(\mathrm{VI})$ and $\mathrm{Cu}(\mathrm{II})$ by waste tea fungal biomass, Ecol. Eng., 2008, 34(2), 179-186.

43 M. Fomina and G. M. Gadd, Biosorption: current perspectives on concept, definition and application, Bioresour. Technol., 2014, 160, 3-14.

44 A. P. Stafussa, G. M. Maciel, A. G. da Silva Anthero, et al., Biosorption of anthocyanins from grape pomace extracts by waste yeast: kinetic and isotherm studies, J. Food Eng., 2016, 169, 53-60.

45 I. Letnik, R. Avrahami, R. Port, et al., Biosorption of copper from aqueous environments by Micrococcus luteus in cell suspension and when encapsulated, Int. Biodeterior. Biodegrad., 2017, 116, 64-72.

46 T. S. Wang, X. Y. Zheng, X. Y. Wang, et al., Different biosorption mechanisms of Uranium(VI) by live and heatkilled Saccharomyces cerevisiae under environmentally relevant conditions, J. Environ. Radioact., 2017, 167, 92-99.

47 L. Z. Huang, G. M. Zeng, D. L. Huang, et al., Biosorption of cadmium (II) from aqueous solution onto Hydrilla verticillata, Environ. Earth Sci., 2010, 60(8), 1683-1691.

48 A. Mishra, B. D. Tripathi and A. K. Rai, Biosorption of Cr(VI) and Ni(II) onto Hydrilla verticillata dried biomass, Ecol. Eng., 2014, 73, 713-723.

49 E. Lopez Errasquin and C. Vazquez, Tolerance and uptake of heavy metals by Trichoderma atroviride isolated from sludge, Chemosphere, 2003, 50(1), 137-143.

$50 \mathrm{Z}$. Aksu, Equilibrium and kinetic modelling of cadmium(II) biosorption by $C$. vulgaris in a batch system: effect of temperature, Sep. Purif. Technol., 2001, 21(3), 285-294.

51 Q. Peng, Y. Liu, G. Zeng, et al., Biosorption of copper(II) by immobilizing Saccharomyces cerevisiae on the surface of chitosan-coated magnetic nanoparticles from aqueous solution, J. Hazard. Mater., 2010, 177(1), 676-682.

52 S. Amirnia, M. B. Ray and A. Margaritis, Heavy metals removal from aqueous solutions using Saccharomyces cerevisiae in a novel continuous bioreactor-biosorption system, Chem. Eng. J., 2015, 264, 863-872.

53 J. M. do Nascimento, J. D. de Oliveira, A. C. L. Rizzo, et al., Biosorption $\mathrm{Cu}$ (II) by the yeast Saccharomyces cerevisiae, Biotechnol. Rep., 2019, 21, e00315.

54 L. Uzun, N. Sağlam, M. Safarikova, et al., Copper Biosorption on Magnetically Modified Yeast Cells Under Magnetic Field, Sep. Sci. Technol., 2011, 46(6), 1045-1051.

55 J. Yu, M. Tong, X. Sun, et al., Enhanced and selective adsorption of $\mathrm{Pb} 2+$ and $\mathrm{Cu} 2+$ by EDTAD-modified biomass of baker's yeast, Bioresour. Technol., 2008, 99(7), 2588-2593.

56 Y. Zhang, W. Liu, M. Xu, et al., Study of the mechanisms of $\mathrm{Cu}^{2+}$ biosorption by ethanol/caustic-pretreated baker's yeast biomass, J. Hazard. Mater., 2010, 178(1-3), 1085-1093.

57 A. Stanila, T. Mihaiescu, C. Socaciu, et al., Removal of Copper and Lead Ions from Aqueous Solution Using Brewer Yeast as Biosorbent, Rev. Chim., 2016, 67(7), 1276-1280.

58 S. Tonk, B. Nagy, A. Toeroek, et al., Cd(II), Zn(II) and Cu(II) Bioadsorption on Chemically Treated Waste Brewery Yeast Biomass: The Role of Functional Groups, Acta Chim. Slov., 2015, 62(3), 736-746.

59 A. M. Stanescu, L. Stoica, C. Constantin, et al., Physicochemical Characterization and Use of Heat Pretreated Commercial Instant Dry Baker's Yeast as a Potential Biosorbent for Cu(II) Removal, Clean: Soil, Air, Water, 2014, 42(11), 1632-1641.

$60 \mathrm{P}$. Yilmazer and N. Saracoglu, Bioaccumulation and biosorption of copper(II) and chromium(III) from aqueous solutions by Pichia stipitis yeast, J. Chem. Technol. Biotechnol., 2009, 84(4), 604-610.

61 I. Zinicovscaia, N. Yushin, D. Grozdov, et al., Metal Removal From Complex Copper Containing Effluents by Waste Biomass of saccharomyces cerevisiae, Ecol. Chem. Eng. S, 2020, $27(3), 415-435$.

62 J. C. Jos, K. B. Debs, G. Labuto, et al., Synthesis, characterization, and application of yeast-based magnetic bionanocomposite for the removal of $\mathrm{Cu}(\mathrm{II})$ from water, Chem. Eng. Commun., 2019, 206(11), 1581-1591.

63 C. Cojocaru, M. Diaconu, I. Cretescu, et al., Biosorption of copper(II) ions from aqua solutions using dried yeast biomass, Colloids Surf., A, 2009, 335(1-3), 181-188.

64 D. Brady, A. D. Stoll, L. Starke, et al., Chemical and enzymatic extraction of heavy metal binding polymers from isolated cell walls of Saccharomyces cerevisiae, Biotechnol. Bioeng., 1994, 44(3), 297-302.

65 X. Li, W. L. Yang, H. J. He, et al., Responses of microalgae Coelastrella sp to stress of cupric ions in treatment of anaerobically digested swine wastewater, Bioresour. Technol., 2018, 251, 274-279.

66 O. D. Iseri, D. A. Korpe, E. Yurtcu, et al., Copper-induced oxidative damage, antioxidant response and genotoxicity in Lycopersicum esculentum Mill. and Cucumis sativus L, Plant Cell Rep., 2011, 30(9), 1713-1721. 
67 M. Saleem, N. Wongsrisujarit and S. Boonyarattanakalin, Removal of nickel (II) ion by adsorption on coconut copra meal biosorbent, Desalin. Water Treat., 2015, 57(12), 56235635.

68 X. G. Luo, F. Liu, Z. F. Deng, et al., Removal of copper(II) from aqueous solution in fixed-bed column by carboxylic acid functionalized deacetylated konjac glucomannan, Carbohydr. Polym., 2011, 86(2), 753-759.

69 X. C. Chen, Y. P. Wang, Q. Lin, et al., Biosorption of copper(II) and zinc(II) from aqueous solution by Pseudomonas putida CZ1, Colloids Surf., B, 2005, 46(2), 101-107.

70 F. Liu, X. G. Luo, X. Y. Lin, et al., Removal of copper and lead from aqueous solution by carboxylic acid functionalized deacetylated konjac glucomannan, J. Hazard. Mater., 2009, 171(1-3), 802-808.

71 G. Z. Kyzas and D. N. Bikiaris, Recent Modifications of Chitosan for Adsorption Applications: A Critical and Systematic Review, Mar. Drugs, 2015, 13(1), 312-337.

72 H. Saito, Y. Yoshioka, N. Uehara, et al., Relationship between conformation and biological response for $(1 \rightarrow 3)$-beta-Dglucans in the activation of coagulation factor $G$ from limulus amebocyte lysate and host-mediated antitumor activity. Demonstration of single-helix conformation as a stimulant, Carbohydr. Res., 1991, 217, 181-190.

73 M. Kostic, M. Radovic, J. Mitrovic, et al., Using xanthated Lagenaria vulgaris shell biosorbent for removal of $\mathrm{Pb}$ (II) ions from wastewater, J. Iran. Chem. Soc., 2014, 11(2), 565578.

74 M. R. Lasheen, N. S. Ammar and H. S. Ibrahim, Adsorption/ desorption of $\mathrm{Cd}(\mathrm{II}), \mathrm{Cu}$ (II) and $\mathrm{Pb}$ (II) using chemically modified orange peel: Equilibrium and kinetic studies, Solid State Sci., 2012, 14(2), 202-210.

75 M. Bansal, U. Garg, D. Singh, et al., Removal of Cr(VI) from aqueous solutions using pre-consumer processing agricultural waste: A case study of rice husk, J. Hazard. Mater., 2009, 162(1), 312-320.

76 A. Celekli and H. Bozkurt, Bio-sorption of cadmium and nickel ions using Spirulina platensis: Kinetic and equilibrium studies, Desalination, 2011, 275(1-3), 141-147.
77 M. R. Pouya and S. Behnam, Adsorption behavior of copper ions on alga Jania adhaerens through SEM and FTIR analyses, Sep. Sci. Technol., 2017, 52(13), 2062-2068.

$78 \mathrm{~S}$. Wierzba, Biosorption of nickel (II) and zinc (II) from aqueous solutions by the biomass of yeast Yarrowia lipolytica, Pol. J. Chem. Technol., 2017, 19(1), 1-10.

79 C. Chen, J. Hu and J. L. Wang, Uranium biosorption by immobilized active yeast cells entrapped in calciumalginate-PVA-GO-crosslinked gel beads, Radiochim. Acta, 2020, 108(4), 273-286.

80 Q. W. Dai, F. Q. Dong and W. Zhang, Biosorption of Lead Ions on Dried Waste Beer Yeast and the Analysis by FTIR, Spectrosc. Spectral Anal., 2009, 29(7), 1788-1792.

81 H. L. Peng, D. Li, J. Ye, et al., Biosorption behavior of the Ochrobactrum MT180101 on ionic copper and chelate copper, J. Environ. Manage., 2019, 235, 224-230.

82 H. Huang, Q. Jia, W. Jing, et al., Screening strains for microbial biosorption technology of cadmium, Chemosphere, 2020, 251, 126428.

83 J. Yang, F. Q. Dong, Q. W. Dai, et al., Biosorption of Radionuclide Uranium by Deinococcus Radiodurans, Spectrosc. Spectral Anal., 2015, 35(4), 1010-1014.

84 A. K. Lakra, L. Domdi, Y. M. Tilwani, et al., Physicochemical and functional characterization of mannan exopolysaccharide from Weissella confusa MD1 with bioactivities, Int. J. Biol. Macromol., 2020, 143, 797-805.

85 A. Acemi, O. Cobanoglu and S. Turker-Kaya, FTIR-based comparative analysis of glucomannan contents in some tuberous orchids, and effects of pre-processing on glucomannan measurement, J. Sci. Food Agric., 2019, 99(7), 3681-3686.

86 S. Nigam, K. Gopal and P. S. Vankar, Biosorption of arsenic in drinking water by submerged plant: Hydrilla verticilata, Environ. Sci. Pollut. Res., 2013, 20(6), 4000-4008.

87 Y. Khambhaty, K. Mody, S. Basha, et al., Biosorption of Cr(VI) onto marine Aspergillus niger: experimental studies and pseudo-second order kinetics, World J. Microbiol. Biotechnol., 2009, 25(8), 1413-1421.

88 H. F. Li, Y. B. Lin, W. M. Guan, et al., Biosorption of Zn(II) by live and dead cells of Streptomyces ciscaucasicus Strain CCNWHX 72-14, J. Hazard. Mater., 2010, 179(1-3), 151-159. 